\title{
EESTLASTE EESNIMED 1900. AASTAL
}

\author{
ANNIKA HUSSAR
}

Annotatsioon. Artikkel avab lähemalt Emakeele Seltsi 2009. aasta Veski päeva konverentsil tutvustatud ja varem põgusalt viidatud uurimuse tulemusi 1900. aasta eesnimekasutuse kohta praegusel Eesti alal (Hussar 2012: 35-37). XIX sajandi teisel poolel hakkas eestlaste eesnimistu teadaolevalt muutuma (nt Roos 1962; Rajandi, Tarand 1976; Hussar 2010, 2012). XIX ja XX sajandi piirimaa on huvitav vahekokkuvõtte punkt, mis annab infot, kuidas ja kui ulatuslikult on nimed uute nimede vastu vahetunud; kus on enam kasutatud traditsioonilisi laennimesid ja kus on uuenduslikud eestipärased nimed varem kasutusse tulnud; missugune valik on tehtud võõrapäraste nimede hulgast; kas eelistused on sarnased või piirkonniti erinevad; kui ulatuslikud on erinevused linna- ja maakoguduste vahel; missuguseks oli selleks ajaks kujunenud just XIX sajandil laiemalt levima hakanud uus joon nimekasutuses - kahe ja enama nime kasutus jne. Seda ajajärku on üsna vähe uuritud nii sünniregistrite kui ka tegeliku, igapäevase nimekasutuse koha pealt. Eduard Roosilt (1962) on artikkel eesnimede kohta XIX ja XX sajandi vahetusel, Hildegard Mustalt (1964) ülevaade nimekasutusest XX sajandi alguses, XIX sajandi lõpu materjali hõlmavad Annika Hussari artiklid (2009, 2010, 2012). Nimede osakaalu on XX sajandi eelsest ajast uurinud nt Henn Saari (1990), Heldur Palli (1959), Lemming Rootsmäe (1969).

Võtmesõnad: onomastika, antroponüümid, eesnimed, kaksiknimed

\section{Materjal}

\subsection{Nimede kirjutamine}

Andmed on kogutud 2003. aastal Siseministeeriumi rahvastiku toimingute osakonna arhiivis leidunud sünnimeetrikatest 1900. aasta kohta. Kaasatud on kõik eesti luteri kogudused, kusjuures kõrvale on jäetud luteri koguduste saksa pihtkonnad, isegi kui nende sünnimeetrikates on kajastatud ilmselgelt eesti päritolu isikuid. Kuivõrd õigeusu traditsioonis on olnud nimede panekul teistsugused tavad ning ettekirjutusi rohkem, on ka õigeusu koguduste sünnimeetrikad kõrvale jäänud. 
Nagu varem nimetatud, on selle aja sünnimeetrikatega üsna keeruline töötada (vt ka Hussar 2012: 39). 1892. aastal jõudis venestamine sünnidokumentidesse ning varasemate saksakeelsete raamatute asemel tulid kasutusele venekeelsed kirikuraamatud ja koguduste raamatud vahetusid. Mitmes koguduses on samal ajal jätkatud saksakeelsete raamatute pidamist, need on ilmselt osalt jäänud mustandiraamatuteks ja neid on täidetud täissaamiseni. Need mustandiraamatud või muul põhjusel peetud saksakeelsed raamatud on olnud suureks abiks nimede väljakirjutamisel. Vene keele kasutamine on nimesid tublisti moonutanud; lisaks on kirjapanijatel olnud oma põhimõtted nimede kirjutamisel ning seepärast on nimedest arusaamisega teinekord üpris suuri raskusi. See tähendab, et nimekasutuse üldsuundumusi on võimalik teada saada, ent mõned nüansid võivad materjali analüüsis siiski kaotsi minna.

Tolleaegsed venekeelsed sünnimeetrikad saab jagada kolmeks.

Osa kirjutajaid on valinud sellise lahenduse, et ehkki muu tekst on venekeelne, on laste eesnimed kirjutatud ladina tähtedega või on nimed esitatud paralleelselt nii ladina kui ka vene tähtedega, üks neist variantidest sulgudes (nt ka Hussar 2012: 39). Peale ristitute nimede on ladina tähtedega lisatud mõnikord ka perekonnanimi ja/või isanimi moonutamata kujul. Küllap on seda tehtud praktilistel põhjustel, et nimed eri raamatutes ühtmoodi kirjas oleks ning neid saaks omavahel kokku viia. Sellises raamatus võib olla järjestikku registreeritud kolm tüdrukut, kellel on kõigil nimi Мария, sulgudes on aga ühel märgitud Marie, teisel Mari ja kolmandal Marin (Hussar 2012: 39).

Teine variant on puhtvenekeelsed raamatud, kus ka nimed on kirillitsas. Neiski on erinevusi. Osa kirjutajaid on üritanud nimedel vahet teha: eespool toodud näite põhjal on Марие, Мари ја Марин võimalikult täpselt kirja pandud.

Kolmas variant on puhtvenekeelsed raamatud, milles nimed on variante arvesse võtmata ühtlustatult kirja pandud: nt Maried ja Marid on kõik Мария'd. See teeb võimatuks uurida seda, kuidas kasutati naisenimede $e$ - ja $a$-lõpulisi variante või kas ristimisel sai laps varasema laenulise nimekuju või moodsa aja võõrapärase variandi. Mõnikord saab kinnitust tegelike kavatsuste kohta ametnike hiljem (nt nimede eestistamisel) tehtud märkustest, kus nimi on kirjas selle tegeliku kasutuse järgi. Päris uute nimede kasutuseletuleku uurimist see siiski ei takista: Эйльме's on võimalik ära tunda Õilmet, Залме's Salmet, Гуго(н) on Hugо, Гельми 
on Helmi ja Гильда Hilda. Selliseid puhtvenekeelseid kogudusi, kus nimed on ühetaoliseks ühtlustatud, on siiski vaid üksikuid. Suurem osa kirjutajatest kasutab eri nimevariante ning see võimaldab saada nimeeelistustest ülevaadet.

Kõige paremini sobivad uurimistööks saksakeelsed (mustandi)raamatud, mille puhul võib probleeme tekitada kirjutaja käekiri, ent nimed on siiski arusaadavad.

Säärane üleminekuaeg ei olnud kindlasti kerge ka sündide kirjapanijatele, mis paneb küsima, kas neil oma töös ka midagi abiks oli. Mõnegi koguduse sünnimeetrika vahel on säilinud A3-formaadis üheleheküljeline saksakeelne juhend nimede kirjutamiseks vene keeles (vt Regeln). Sellel väljaandmise aastat kirjas ei ole. Juhend on digiteeritud ja näha mõne sünnimeetrikaga koos Rahvusarhiivi Saaga lehel, nt Viru-Jaagupi 1900. aasta sünnimeetrika esilehel on see olemas. Samalaadseid juhiseid annab paljude Vene impeeriumis kõneldud väikekeelte nimede kohta konsistooriumi raamatuke „Ministeriell bestätigte Vorschriften des Evangelisch-luterischen General-Konsistoriums betreffend die Führung der Kirchenbücher (метрические книги) in russischer Sprache“ (1899). Soome, rootsi, läti, saksa jt keeltes nimede kõrval on esindatud ka eesti nimed. Iga peatüki alguses on esitatud üldised reeglid, selle järel mehe- ja siis naisenimede loendid ning kuidas neid nimesid kirillitsas kirjutada. Ladina tähestikus nimed järgivad selles väljaandes uut kirjaviisi ja on kirjas häälduspäraselt, nt Aado, Aadu, Kaarel, Kaarle, Kaarli ja ka selline hääldustäpsus kui Eeduart. Kirillitsas vastetest on osa hääldustäpsemad, teised juhatavad tagasi ühise algnime juurde. Näiteks naisenimede Edu, Eedu, Eeduga, Hedi, Hedo, Hedu vasteteks on märgitud Хедвига, Ядвига, aga Hebo vasteks on kirjas Хебо ja Неbи vasteks Хебу. Ilmselt ei ole viimastele nimedele nii selget ühist algnime leitud.

Kõnealuse raamatu juhised on kohati üsna lihtsustatud ja tekitasid küsimusi ka selle ilmumise järel. 1901. aastal arvustab sealseid reegleid Juhan Luiga: „Üksinda eesti nimestikus tulevad sääl nimede kokkutõmbamise kriipsud ette, terve nimestiku kohta enam kui 70 korda, ja tihti tõmbavad nad juure rea nimesid, 5, 6, koguni 8 nime ühtekokku; pääle nende kriipsude, juhatab paljude nimede juures täht s. (s.o siehe!) teiste nimede juurde, n. näit. 1k. 25 Mall, vt Maala. Viimane nimi tuleb vene keeli Amalija kirjutada, Mall siis niisama, aga kuidas siis vahet teha, kui ühel õel nimi Maali, teisel Mall?" Huvitav on see, et juhised on eesti nimede 
suhtes teiste keeltega võrrelduna jäigad ning eesti keeles erisugused nimed sulavad vene keeles kokku üheksainsaks variandiks, ehkki teistes keeltes on mitut varianti võimalikuks peetud. Kui levinud juhendiraamat oli, ei ole teada, kirjapanekute järgi on sellest abi olnud - seda on näha neist raamatuist, kus nimed on paralleelselt esitatud.

Suurema osa koguduste puhul on siiski tänu saksakeelsetele paralleelraamatutele või siis seetõttu, et nimesid on märgitud nii vene kui ka saksa moodi, võimalik ladinatähelist kasutust jälgida. Kuivõrd tollel ajal on nimede kirjapanek küllalt palju olenenud kirjapanija maitsest ja arusaamadest, siis on siinses töös püütud koos vaadata sama nime lähedasi variante, nt Elfriede $\sim$ Elfride $\sim$ Elfriide või $a$ - ja $e$-lõpulised variandid, nagu Marie $\sim$ Maria, Helene $\sim$ Helena . Vanas kirjaviisis, eeskätt varasemat nimekasutust esindavad (laen)nimed, nagu nt Jula, Rudo, Lena, on esitatud tänapäevases kirjaviisis. Eri nimedena on aga käsitletud juhtumeid, nagu Marie/a - Mari, Helene/a - Leena.

\subsection{Nimede ja laste arv}

Laste koguarv on siinses uurimuses 22 738, sh 11297 tüdrukut ja 11441 poissi. Kaasatud on Eestimaa ja Liivimaa kubermangu ning Narva linna luteri koguduste materjal, uurimuses käsitletud kogudusi on kokku 124.

Andmeid on analüüsitud eeskätt toonaste maakondade kaupa, omaette vaatluse all on Hiiumaa kui võrdlemisi eraldatud piirkond. Lisaks on linna- ja maakoguduste võimalike erinevuste väljatoomiseks omaette vaadeldud kahe linna, Tallinna ja Tartu materjali. Et saada ettekujutust tööstuse arengu mõjust selle kaudu, et olid tekkinud suured keskused, kuhu tuli inimesi teistest piirkondadest, on tänapäeva Eesti alalt vaatluse all ka suur, ulatusliku eesti kogukonnaga tööstuskeskus Narva.

Lastele on kokku pandud 774 nime, sh 425 naisenime ja 349 mehenime. (Siin ja edaspidi on silmas peetud ainult ristimisel esimesele kohale seatud nimesid ehk esinimesid, mitmiknimede teisi nimesid vaadeldud ei ole.)

Lemming Rootsmäe (1969: 623) ütleb Võnnu kihelkonna XVIII sajandi nimekasutuse kohta, et kogu sajandi jooksul kasutati kokku 122 mehenime ja 94 naisenime. Ka Edgar Rajandi andmed kõnelevad sellest, et naisenimesid oli XVIII sajandil vähem kasutusel kui mehenimesid (Rajandi 1963: 177). Sama iseloomustab nt naabermaa Soome eesnime- 
kasutust (Kiviniemi 1982: 175-176). Ka XIX sajandi alguse Eesti- ja Liivimaal oli rohkem kasutuses mehenimesid kui naisenimesid (Hussar 2012: 40).

Muutus toimus XIX sajandi teisel poolel koos uute nimede kasutuseletulekuga: uued naisenimed võeti kiiremini ja kergemini tarvitusse, meestel püsisid kauem traditsioonilised nimed ning säilisid kauem ka seosed ristivanemate nimedega (Hussar 2009).

Sellessamas Rootsmäe vaadeldud Võnnu koguduses pandi ainuüksi 1900. aastal 59 mehenime (215 last) ja 58 naisenime (197 last), lisaks on umbes kolmandikul poistest ja kahel kolmandikul tüdrukutest kaks nime, mis võimaldas veelgi rohkem nimekombinatsioone.

Kinnitust leidis, et 1900. aastaks oli kõikjal kasutusel rohkem naisenimesid kui mehenimesid (erandlikult on õige väike vahe mehenimede kasuks Hiiumaal, aga see võib tuleneda pigem vähemast sündide arvust). Linnades on nii tüdrukutele kui ka poistele pandud erinevaid nimesid rohkem, seda näitab nimekandjate väiksem arv ühe nime kohta (vt joonis 1).

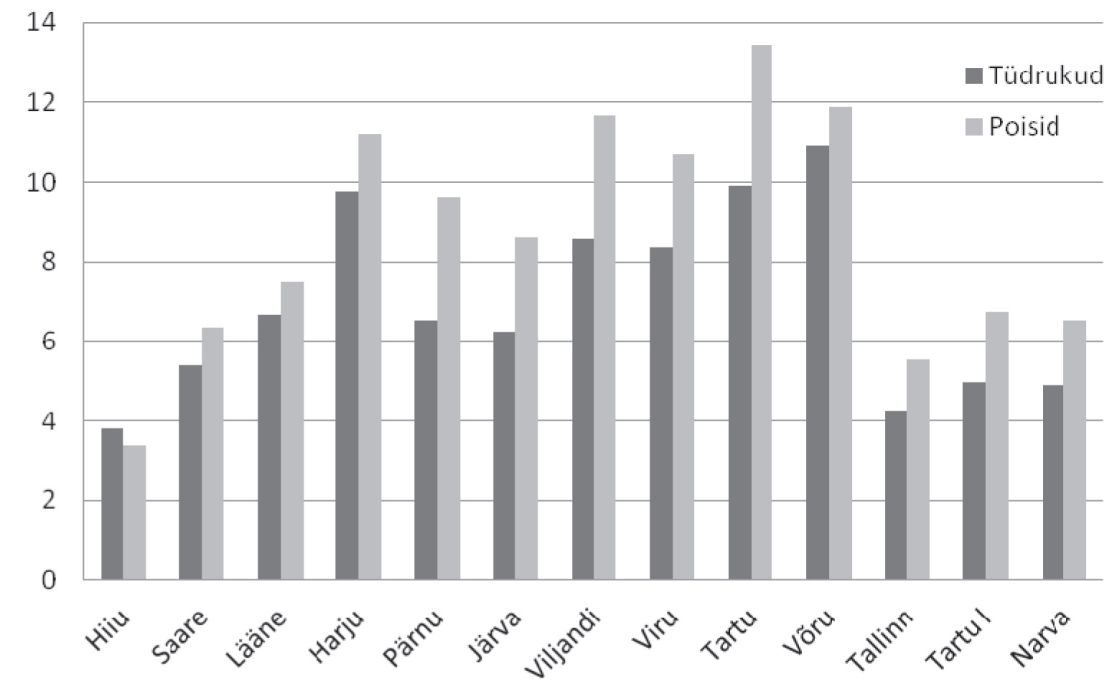

Joonis $\mathbf{1}^{1}$. Nimekandjate arv ühe nime kohta 1900. aastal

1 Joonisel: Tartu 1 - Tartu linn. 


\section{Eelisnimed}

\subsection{Eelisnimede osakaal}

Populaarsemate nimede osakaal oli ka 1900. aastal veel üsna suur - 20 nimest piisas vaadeldud maakondade ja linnade kahele kolmandikule tüdrukutest (linnades küll veidi vähemale) ning isegi kolmveerandile poistest (vt joonised 2 ja 3). Võrdluseks: Kolga-Jaanis piisas 1835. aastal viiest populaarsemast nimest, et nime saaks kaks kolmandikku tüdrukutest ja poistest ning veel 1850. aastal üle poole tüdrukutest ja kaks kolmandikku poistest (Hussar 2010: 198).

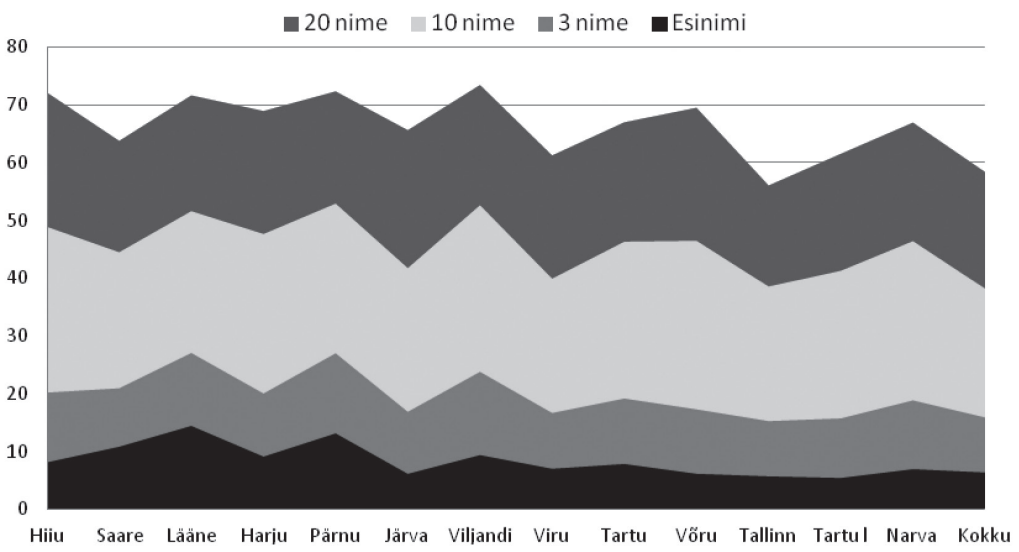

Joonis 2. Tüdrukute eelisnimede osakaal 1900. aastal pandud nimede hulgas

1900. aastal piisas 10-st tavalisemast nimest, et nime saaks olenevalt piirkonnast $40-50 \%$ tüdrukutest, poistel kattis 10 nime $45-60 \%$ nimevajadusest, mis teeb kõigi koguduste peale kokku 38,1\% tüdrukute ja $51,3 \%$ poiste nimevajadusest. Eesti nimekasutust saab sageli Soome omaga võrrelda, kuna paljud muutused on eriti XIX-XX sajandi vahetusel olnud samalaadsed. Kümne esinime puhul ilmneb, et need katsid soomlaste nimevajadusest palju väiksema osa, umbes kolmandiku nii tüdrukutel kui ka poistel (Kiviniemi 2006: 24-25). Soome nimekasutus moderniseerus varem - oli Eestile eeskujukski - ning see võib osutada, et soomlaste nimevara on uuenenud ning koos sellega on vähenenud tähtsamate nimede ülekaal, Eesti on aga mõne sammu jagu veel muutustega maas. 


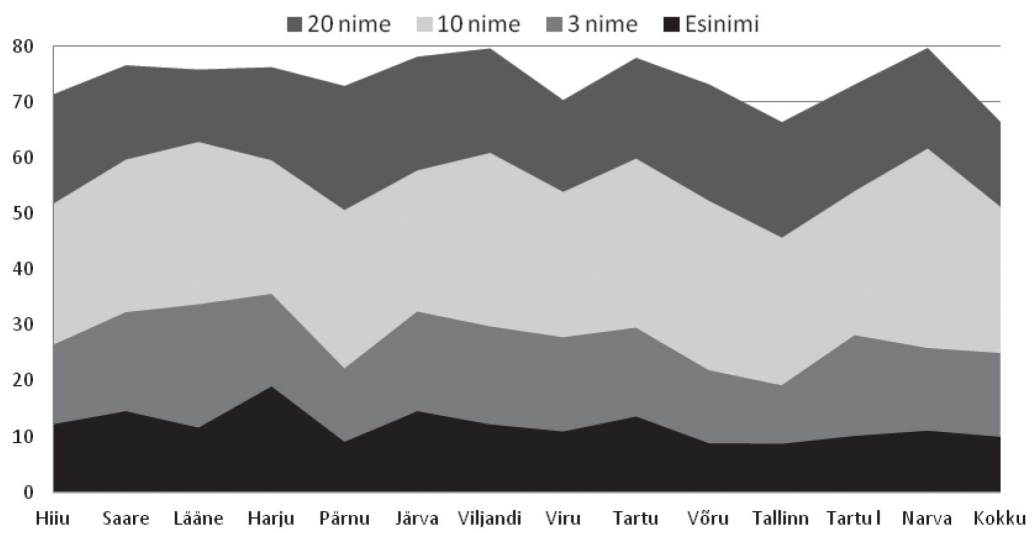

Joonis 3. Poiste eelisnimede osakaal 1900. aastal pandud nimede hulgas

Eesti võrdluses võib lisada, et 30 aastat hiljem, 1930. aastal oli populaarsemate nimede osa veelgi vähenenud. 10 eelisnime seast sai nime ligikaudu $20 \%$ tüdrukutest ja 24\% poistest (Hussar 1998: 44). Kõige vähem katsid 1900. aastal eelisnimed nimevajadusest Tallinnas ja Tartus.

Kõige ülekaalukama kasutusega esinimi oli 1900. aastal naisenimedest Marie/a Läänemaal (14,4\% nimeandmisjuhtudest) ja mehenimedest Johannes Harjumaal (18,9\%). Esinimedest kõige väiksema osakaaluga oli naisenimedest Hilda Tartus (5,4\%) ja mehenimedest Johannes Tallinnas $(8,7 \%)$, maakoguduste naisenimedest Marie/a Järvamaal $(6,1 \%)$ ning mehenimedest August Võrumaal (8,8\%).

\section{2. Üldine nimepilt}

1900. aasta eesnimistu on üsna eripalgeline, eriti kui nimesid kogu ala ulatuses vaadata.

Esiteks leidub selles vanu, juba keskajal laenatud nimesid. Nende osakaal on küll XIX sajandi algupoolega võrreldes oluliselt vähenenud, ent Marid, Reedad, Inglid, Tõnised, Märdid, Jaanid ja Jürid on ikka veel esindatud.

Teiseks on laialdaselt kasutusel võõrapärased nimed. Need saab kasutuseletuleku põhjal jagada kolme rühma.

Nagu varem näidatud (Hussar 2012: 36), tulid esmalt kasutusele juba tarvituses olnud laennimede võõrapärased vasted. Jaani asemel hakati 
kasutama Johannest, Priidiku asemel Friedrichit, Liisa või Liisu asemel pandi tüdrukule nimeks Elisabeth, Leena asemel Helene jne.

Nende kõrval muutusid vastuvõetavaks ja ilmusid järk-järgult kasutusse täiesti uued, eestlaste seas seni tundmata nimed, nagu nt Rosalie, Emma, Alma, Olga, Ellen, Erika; Feliks, Rudolf, Erich, Viktor.

Kolmanda rühma moodustavad eestipärased nimed, mida eeskätt kalendrites esitati ning mida „Kalevipojas“ jt kirjandusteostes leidus ja millest esimesed juba ka laiemat huvi pakkusid.

\subsection{Populaarsemad nimed piirkonniti}

Esmalt olgu esitatud piirkondade populaarsemad nimed (vt tabelid 1 ja 2).

Nagu varem osutatust (Hussar 2012: 37) ja juba nimetatud iseärasuste põhjal selguma on hakanud, tuleb ka esikümne nimesid lähemalt uurides esile, et praeguse Eesti ala saab toonase eesnimekasutuse poolest jagada mõttelise piiriga kaheks: läänepoolseks alalhoidliku ja idapoolseks uuenduslikuma nimekasutusega alaks. Põhja poolt lõuna poole liikudes võib piiri tõmmata Harjumaa ja Virumaa vahele ning Järvamaad ja Viljandimaad

Tabel 1. Populaarsemad naisenimed 1900. aastal piirkonniti

\begin{tabular}{|c|c|c|c|c|c|c|}
\hline Jrk & Hiiumaa & Saaremaa & Läänemaa & Harjumaa & Pärnumaa & Järvamaa \\
\hline 1. & Marie & Marie & Marie & Marie & Marie & Marie \\
\hline 2. & Anna & Ida & Liisa & Annette & Anna & Marta \\
\hline 3. & Liisa & Liisa & Anna & Alide & \multirow{2}{*}{$\begin{array}{l}\text { Hilda } \\
\text { Ida }\end{array}$} & Alma \\
\hline 4. & Alide & Miina & Elvine & Elvine & & Alide \\
\hline 5. & Helene & Juuli & Alide & Hilda & Alma & Hilda \\
\hline 6. & Adele & Eliise & Ann & Anna & Ella & Elfriede \\
\hline 7. & \multirow{2}{*}{$\begin{array}{l}\text { Elvine } \\
\text { Hilda }\end{array}$} & Alvine & Mari & Helene & Liisa & Helene \\
\hline 8. & & Juulie & Annette & Pauline & Alide & Johanna \\
\hline 9. & \multirow{2}{*}{$\begin{array}{l}\text { Marta } \\
\text { Pauline } \\
\text { Salme }\end{array}$} & Liina & Marta & Marta & \multirow{2}{*}{$\begin{array}{l}\text { Agnes } \\
\text { Helmi } \\
\text { Johanna } \\
\text { Juuli }\end{array}$} & Adele \\
\hline 10. & & $\begin{array}{l}\text { Alma } \\
\text { Sofie }\end{array}$ & Leena & Liisa & & Juuli \\
\hline
\end{tabular}


pidada vahealaks, kus leidub nii uuemaid kui ka varasemaid hoiakuid (varasem tava eriti mehenimede puhul).

Laennimed. Ka laennimede puhul kujunes välja lääne-ida jaotus (v.a linnad). Joonisel 4 on laennimede kasutuse andmed järjestatud tüdrukute laennimede osakaalu suurenemise alusel. Selgelt on näha, et poistele pandi laennimesid rohkem kui tüdrukutele (v.a saartel), mis viitab taas sellele, et tüdrukute nimedes on uus mood varem näha. Pärnumaal ja Viljandimaal on erinevused naise- ja mehenimede tarvituses eriti kontrastsed: poistest sai laennime üle kolmandiku, tüdrukutest ligikaudu $15 \%$. Teiseks eristuvad linnad - Tallinn, Narva, Tartu -, kus traditsioonilisi laennimesid pandi vähem kui mujal. See kinnitab varem oletatut, et ehkki ristivanemate osatähtsus oli XIX sajandi lõpuks nagunii oluliselt vähenenud, nõrgenesid linna rännates sidemed perekonnaringi ja kodukandiga - kust lastele tavaliselt ristivanemad leiti - ning linnas leiti nii uued nimed kui ka varasemast erineval viisil ristivanemad (Hussar 2009: 525). Näiteks kõigi koguduste populaarseimat naiste laennime Liisa, mis on 13. kohal ja mis on kogu Läänemaal üks tavalisemaid naisenimesid üldse, ei pandud Tallinnas 1900. aastal kordagi. Samuti on Läänemaal populaarne Mari mujal nii loomulikult Marie vastu vahetunud, et esineb lisaks veel ainult

\begin{tabular}{|c|c|c|c|c|c|c|c|}
\hline $\begin{array}{c}\text { Viljandi- } \\
\text { maa }\end{array}$ & $\begin{array}{c}\text { Viru- } \\
\text { maa }\end{array}$ & $\begin{array}{c}\text { Tartu- } \\
\text { maa }\end{array}$ & $\begin{array}{c}\text { Võru- } \\
\text { maa }\end{array}$ & Tallinn & Tartu & Narva & Kokku \\
\hline Marie & Alide & Alide & Ella & Elfriede & Hilda & Marie & Marie \\
\hline Anna & Helene & Salme & Alide & Hilda & \multirow{2}{*}{$\begin{array}{l}\text { Alide } \\
\text { Elfriede }\end{array}$} & Alide & Alide \\
\hline Ella & Hilda & Alma & Alma & Alide & & Ida & Hilda \\
\hline Liisa & Marie & Ida & Emilie & Helene & Marta & Helene & Anna \\
\hline Alma & Alma & Ella & Anna & Marta & Linda & Adele & Alma \\
\hline Alide & Olga & Hilda & Emma & Alma & Salme & Elfriede & Ida \\
\hline Ida & \multirow{2}{*}{$\begin{array}{l}\text { Annette } \\
\text { Ida }\end{array}$} & Emilie & Hilda & Amanda & Alma & Alma & Helene \\
\hline Johanna & & \multirow{2}{*}{$\begin{array}{l}\text { Adele } \\
\text { Linda }\end{array}$} & Olga & Marie & \multirow{2}{*}{$\begin{array}{l}\text { Emilie } \\
\text { Marie }\end{array}$} & Hilda & Ella \\
\hline Hilda & Amanda & & Ida & Johanna & & \multirow{2}{*}{$\begin{array}{l}\text { Anna } \\
\text { Linda }\end{array}$} & Salme \\
\hline Linda & Elfriede & Anna & Alvine & Olga & Ida & & Marta \\
\hline
\end{tabular}


Tabel 2. Populaarsemad mehenimed 1900. aastal piirkonniti

\begin{tabular}{|c|c|c|c|c|c|c|}
\hline Jrk & Hiiumaa & Saaremaa & Läänemaa & Harjumaa & Pärnumaa & Järvamaa \\
\hline 1. & Johannes & Aleksander & August & Johannes & Jaan & Johannes \\
\hline 2. & Eduard & August & \multirow{2}{*}{$\begin{array}{l}\text { Jaan } \\
\text { Johannes }\end{array}$} & August & August & August \\
\hline 3. & \multirow{2}{*}{$\begin{array}{l}\text { Aleksander } \\
\text { August }\end{array}$} & Eduard & & Aleksander & Karl & Aleksander \\
\hline 4. & & Oskar & Aleksander & Eduard & Johannes & Rudolf \\
\hline 5. & Rudolf & Johannes & Mihkel & Rudolf & Aleksander & Karl \\
\hline 6. & \multirow{2}{*}{$\begin{array}{l}\text { Evald } \\
\text { Villem }\end{array}$} & Mihkel & Karl & Jaan & Juhan & \multirow{2}{*}{$\begin{array}{l}\text { Eduard } \\
\text { Voldemar }\end{array}$} \\
\hline 7. & & Peeter & \multirow{2}{*}{$\begin{array}{l}\text { Eduard } \\
\text { Jüri }\end{array}$} & Julius & Peeter & \\
\hline 8. & Oskar & Karl & & \multirow{2}{*}{$\begin{array}{l}\text { Hans } \\
\text { Jüri }\end{array}$} & Eduard & Arnold \\
\hline 9. & \multirow{2}{*}{$\begin{array}{l}\text { Anton } \\
\text { Hermann } \\
\text { Peeter } \\
\text { Teodor }\end{array}$} & Jakob & Anton & & Martin & \multirow{2}{*}{$\begin{array}{l}\text { Gustav } \\
\text { Oskar } \\
\text { Otto }\end{array}$} \\
\hline 10. & & $\begin{array}{l}\text { Aado } \\
\text { Jaen } \\
\text { Juhan } \\
\text { Julius } \\
\text { Jüri }\end{array}$ & Hans & Voldemar & Hendrik & \\
\hline
\end{tabular}

saartel, mõne korra Pärnu- ja Viljandimaal ning üks kord nii Võrumaal kui ka Tartus. Läänemaal on esikümnes nii varasema kasutuse Mari kui ka uue aja Marie, samas on üheskoos nii Ann kui ka Anna. Mehenimede seas tuleb selliseid vana-uue paare esikümnes ette rohkemates piirkondades, nt Johannese kõrval esinevad Jaan (Jaen), Juhan ja Hans.

Varem oma piirkonnale iseloomulikke nimesid tuleb esile õige harva: naisenimedest Aet Hiiumaal (1 kord), Els Pärnu- ja Viljandimaal (kummaski 1), Epp Viljandimaal (1), Katre ja Katri Võrumaal (kumbagi 1), Saaremaal veel Ingel (2), Ruudu (2), Triin (7), Viia ja Viiu (vastavalt 6 ja 4); mehenimedest Ernits Virumaal (2), Justin Võrumaal (1), Magnus Hiiumaal ja Harjumaal (vastavalt 3 ja 2), Matt Viljandimaal (1), Märt Pärnu- ja Viljandimaal (vastavalt 10 ja 3), Reinut Läänemaal (2), Tiidrik Virumaal (2), Saaremaal veel Jaen (7), Laas (4), Reedik (1), Riidu (3), Vassil (4).

Sagedamini esinenud laennimede hulgas on nt Liisa, Ann, Mari, Leena, Miina, Liina. Poisid said kõige sagedamini nimeks Jaan, mis on laennimedest ka ainsana üle Eesti esikümnes, peale selle veel nt Jüri, Peeter, Mihkel, Kaarel, Juhan. 


\begin{tabular}{|c|c|c|c|c|c|c|c|}
\hline Viljandimaa & Virumaa & Tartumaa & Võrumaa & Tallinn & Tartu & Narva & Kokku \\
\hline August & Johannes & August & August & Johannes & Karl & Johannes & August \\
\hline Jaan & August & Johannes & Eduard & $\begin{array}{l}\text { Aleksan- } \\
\text { der }\end{array}$ & August & August & Johannes \\
\hline Hans & Aleksander & Karl & Alfred & Karl & Johannes & Voldemar & Aleksander \\
\hline Johannes & Eduard & Eduard & Oskar & Voldemar & Eduard & Eduard & Eduard \\
\hline Juhan & Karl & Aleksander & Karl & Alfred & Aleksander & Aleksander & Karl \\
\hline Eduard & Voldemar & Jaan & Rudolf & \multirow{3}{*}{$\begin{array}{l}\text { Arnold } \\
\text { August } \\
\text { Richard }\end{array}$} & Rudolf & Richard & Jaan \\
\hline Karl & Rudolf & Oskar & Paul & & \multirow{2}{*}{$\begin{array}{l}\text { Artur } \\
\text { Voldemar } \\
\end{array}$} & Rudolf & Rudolf \\
\hline Aleksander & Arnold & Rudolf & Jaan & & & \multirow{2}{*}{$\begin{array}{l}\text { Albert } \\
\text { Oskar }\end{array}$} & Oskar \\
\hline Jüri & Heinrich & Voldemar & Osvald & \multirow{2}{*}{$\begin{array}{l}\text { Eduard } \\
\text { Oskar }\end{array}$} & \multirow{2}{*}{$\begin{array}{l}\text { Alfred } \\
\text { Ernst } \\
\text { Oskar }\end{array}$} & & Voldemar \\
\hline Martin & Karla & $\begin{array}{l}\text { Arnold } \\
\text { Elmar }\end{array}$ & Richard & & & $\begin{array}{l}\text { Adolf } \\
\text { Robert }\end{array}$ & Arnold \\
\hline
\end{tabular}

Võõrapärased nimed. Kui tolleaegset nimekasutust lühidalt iseloomustada, siis võib selle kohta öelda „võõrapärasus“ - eesnimistust on kadumas eesti keelde mugandunud ja pikalt tarvituses olnud laennimed ning pisut on märke uuest, eestipäraste nimede moest, ent valdavalt saavad lapsed võõrapärase nime.

Kui tabelites 1 ja 2 esitatud esikümmet järgmise kümne võrra pikendada, leiaks sealt kogu Eesti kohta naisenimed Emilie, Elfriede, Liisa, Linda, Johanna, Pauline, Adele, Olga, Annette, Julie ja mehenimed Alfred, Richard, Paul, Artur, Julius, Hans, Heinrich, Jüri, Juhan, Peeter.

Ehkki esmapilgul tunduvad võõrapärased nimed eri maakondades üsna ühedsamad olevat, siis lähemalt uurides see nõnda pole. Kõige populaarsem naisenimi Marie puudub esikümnest Tartumaal (on 12. kohal) ja Võrumaal (15.). Seega saab öelda, et laennimede asemel nende rahvusvaheliste vastete kasutamise etapp on kas läbitud või pole seda olnudki. $\mathrm{Nt}$ Palamusel pole kogu XIX sajandi jooksul Marie olnud esinimi; see nimi oli moes 1860.-1870. aastatel, kuid jõudis ka siis vaid eelisnimede seas 3. kohale (vt ka Hussar 2012: 49). Marie on esinimi kõigis läänepoolsetes 


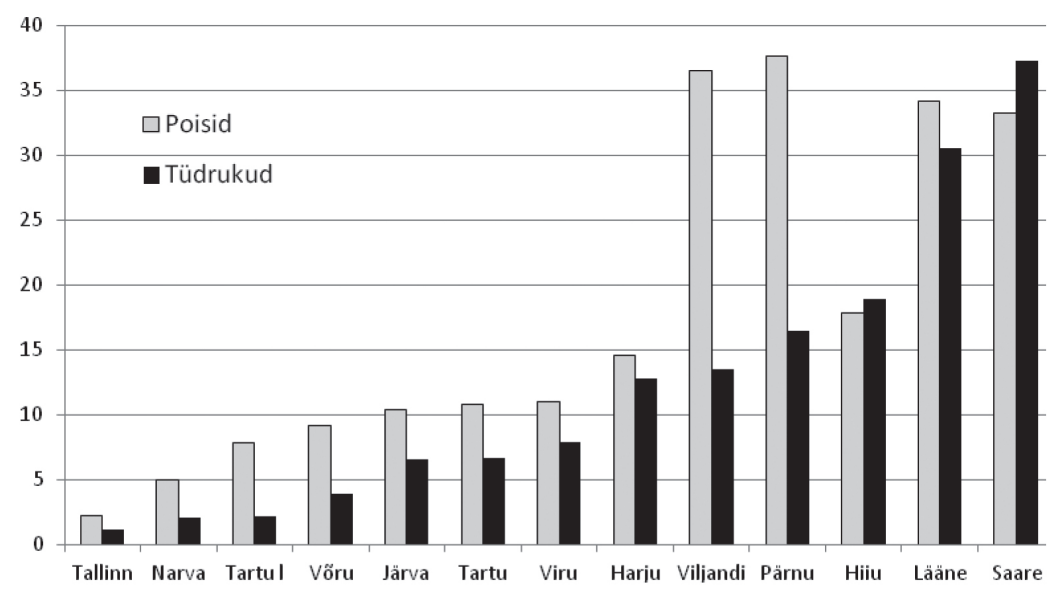

Joonis 4. Laennimede osakaal 1900. aastal pandud nimede hulgas piirkonniti

maakondades, samuti vahealadel Järva- ja Viljandimaal ning Narvas. Mariet võib pidada eelmise nimepanekutava Mari asendusnimeks. Samalaadsed asendusnimed Anna, Annette, Helene on piirkonniti erinevalt esindatud. Järgmine populaarne nimi Alide on juba uuema nimemoe esindaja, mis ilmus eestlaste kasutusse 1900. aastale eelnenud paari kümnendi jooksul. Alide puudub esikümnest Saaremaal ning laiemalt vaadates on see läänepoolsetel aladel pingereas tagapool, idapoolsetel eespool, sh esikohal Virumaal ja Tartumaal. Samuti uue nimena pruuki tulnud Hilda puudub Saaremaal ja Läänemaal, kuid on esinimi Tartus. Ka muude uuemate esikümne nimede Alma, Ida, Ella, Marta puhul võib märgata kasutuses ebaühtlust. Siiski võib täheldada, et nende seast suhteliselt uuemad - Alma ja Ella - on pingereas eespool idapoolsetes maakondades ning kõigis linnades. Mõlemad on esikolmikus Võrumaal, kusjuures Ella on esinimi. Märkida tuleks veel, et Tallinna esinimi Elfriede on olemas ka teiste linnade ja Virumaa esikümnes, kuid esineb lääne pool vaid üksikuid kordi ning puudub koguarvestuses esikümnest (on 12.).

Meeste esinimede Augusti ja Johannese kasutus on kõikjal üsna ühtlane, vaheldumisi on need nimed igal pool enamjaolt esiviisikus (Johannes puudub esikümnest Võrumaal). Koguarvult pole Augusteid Johannestest oluliselt rohkem. Üsna ühtlaselt esineb ka sama laadi asendusnimi Karl. Uuemad nimed kogu ala esikümnes on Rudolf, Oskar, Arnold. On üsna ootuspärane, et neid ja teisi uuemaid laene esineb sagedamini idapoolsetes 
piirkondades, mõtteline ala hõlmab uute nimede kasutajana Järvamaa, ent mitte Viljandimaad. Lääne pool tulevad peale nimetatute tipus esile veel Anton ja Evald, ida pool leidub uuenduslikke nimesid rikkalikumalt, nt Albert, Alfred, Ernst, Richard, Elmar, Robert. Kõige uuemate nimedega linnade kõrval tõusevad esile Tartumaa ja Võrumaa. Muutused meeste eelisnimedes on sedavõrd värsked, et 1900. aasta uuemad võõrapärased nimed on ülekaalus veel ka 1920. aastal. Edgar Rajandi ja Helmut Tarand (1971: 213) nimetavad sellest ajast Tallinna mehenimede esikümnes nt Arnoldit ja Elmarit (nende kõrval endiselt ka Johannest). Naisenimede esikümnes kattuvusi 1920. aasta Tallinna esikümne nimedega ei esinenud, ülekaalu olid saanud eestipärased nimed ning nende kõrval veel uuemad võõrapärased nimed (nt Ellen ja Helga).

Eestipärased nimed. Nimevaliku muutused tulevad hästi esile uute, eestipärasust taotlevate nimede leviku uurimisel.

Eestipärasust on käsitletud erinevalt. Eduard Roos (1962: 419) arvas näiteks eestipäraste nimede hulka ka Hilda ja Ella, kuna neid oli eestipärasena tutvustatud ning Roosi hinnangul rahva seas eestipärasena vastu võetud. Hilda oli Andres Saali samanimelise jutustuse tegelane (Roos 1962: 419). Ella puhul peaks arvesse võtma seda, et kui saksa kultuuri endiselt eesti nimedele mõju avaldanuks pidada, siis just 1890. aastatel oli Ella saksa eelisnimede hulgas.

Siinses töös on eestipärasena käsitletud eesti (või lähisugulaskeelte, eeskätt soome) tüvedele toetuvaid nimesid, mida eestipärasena tutvustati ja soovitati. Kirjandusteostest kui nimede levitajast ei saa siiski mööda vaadata ja Linda-millele mitmel moel eestilisust lisati (sama nimega ajakiri, seltsid) ning mis parasjagu saksa tavalisimate nimede hulka (mis ju meie nimekasutust mõjutasid) ei kuulunud - on „Kalevipoja“ nimena loetud eestipäraseks. Naisenimedest olid populaarsemad eestipärased nimed tol ajal Salme (9.), Linda (14.) ja Helmi (23.). Eestipärastest naisenimedest leiab 1900. aasta kasutusest veel nt Aina, Aino, Helma, Helme, Leida, Leili, Salmi, Õie, Õime, neist paljud esinevad vaid korra: Alga, Eha, Elva, Endla, Koidu, Mooni, Pärja Võrumaal, Ainu, Heli, Vaike Virumaal, Lehta ja Leita Tartumaal.

Joonisel 5 on esitatud Eesti ala eestipäraste naisenimede osakaal kasvavas järjekorras.

Kõige vähem on eestipäraseid nimesid pandud Läänemaal, saartel ja Harjumaal; populaarsuse keskmeks on Tartumaa ja Tartu linn koos Viljandi- ja Võrumaaga. 


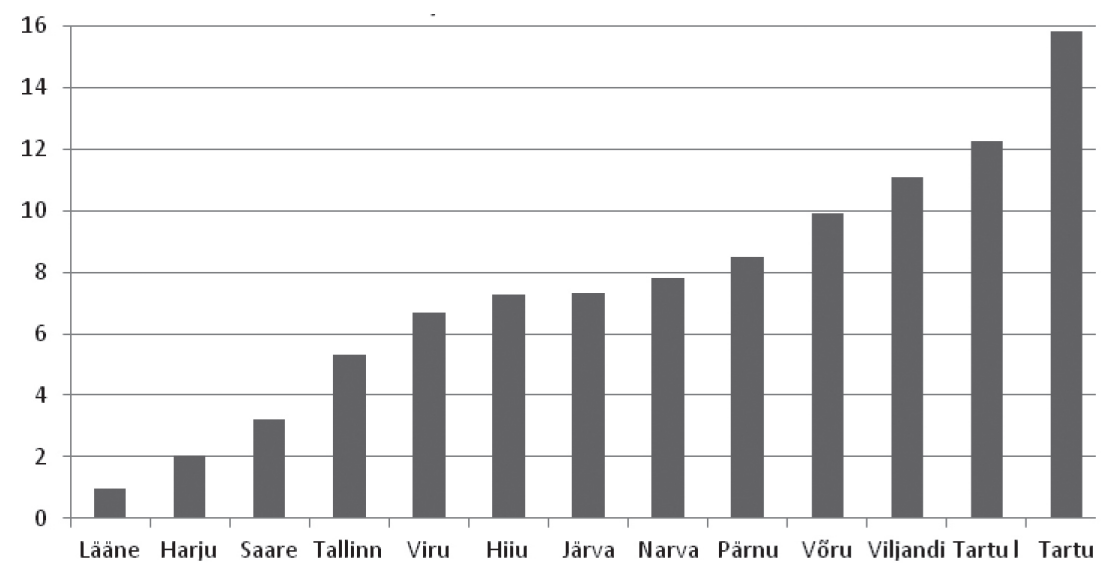

Joonis 5. Eestipäraste naisenimede osakaal 1900. aastal piirkonniti

Mehenimede seas on 1900. aastal alles esimesi üksikuid märke uuest rahvuslikust suunast. Uuritud kogudustes on kogu Eesti ala peale kirja pandud viis Endlit, neli Lembitut ning neli Ilmarit. Ka ülejäänud loetelu pole kuigi pikk ning uute nimede kasutus on üliharv, nt Aari, Kalev, Olev, Pikker, Sulev. Kõige enam esineb taolisi nimesid Võrumaal - 10 korda, mis siiski ei tee kokku protsentigi (0,66\%). Mehenimede esikümnesse jõudsid eestipärased nimed oluliselt hiljem, nende kõrgaeg oli Eestis 1930. aastate keskel nimede eestistamise ajal (Hussar 1998: 49). Mainitud 1920. aastate Tallinna nimede edetabelisse olid jõudnud Lembit ja Endel (Rajandi, Tarand 1971: 213).

\subsection{Kaksiknimed}

Ehkki 1900. aastal tuli ette ka rohkema kui kahe nime panekut, on enamjaolt tegemist siiski kahe nime kombinatsioonidega ja seepärast on eelistatud nimetust kaksiknimi. Kaksiknimed levisid XIX sajandi teisel poolel kogu Eesti alal. 1900. aastaks oli kahe nime komme küllap kõikjal tuttav, ent selle levik väga ebaühtlane, ulatudes tüdrukute puhul linnakogudustes üle 80\%, isegi 90\%-ni (maakogudustest kõige rohkem Rakveres, 82,3\%) ja puududes mõnes kohas täiesti. Tüüpilise uue nimemoe nähtusena on tüdrukud kaksiknimesid rohkem saanud. 


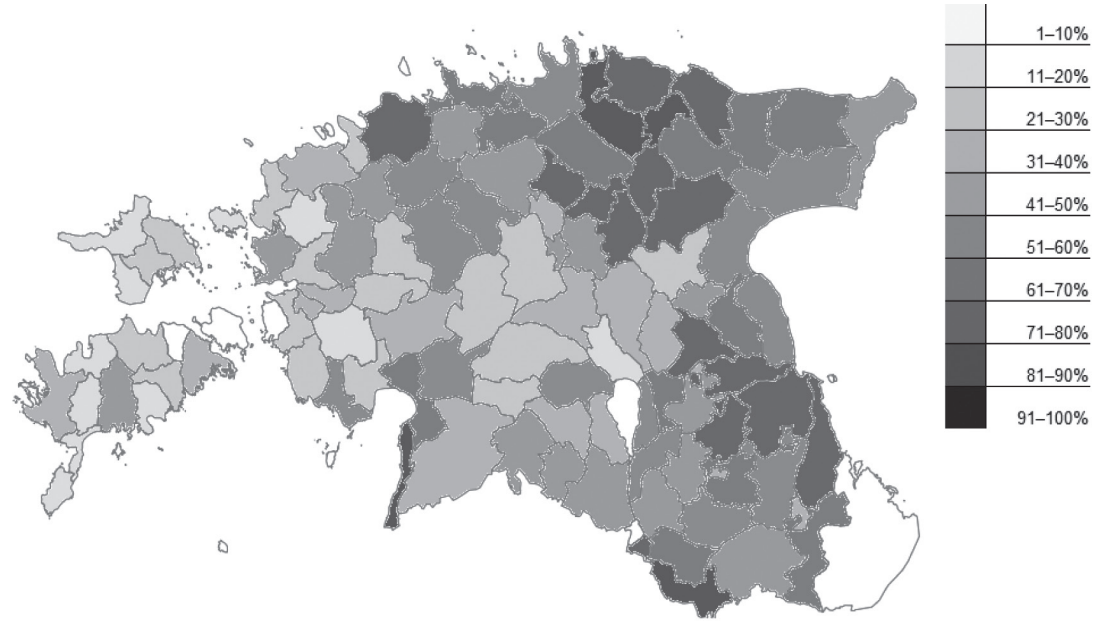

Joonis 6. Tüdrukute kaksiknimede sagedus 1900. aastal kihelkonniti. Kaardil näidatule lisaks: kaksiknimede sagedus Tallinnas oli 70,8\%, Tartus $60,5 \%$ ja Narvas $33,3 \%^{2}$

Kaksiknimede moe kese oli Tallinnas, Virumaal ja Tartus, järgnevad Järvamaa, Võrumaa ja Tartumaa. Lääne pool esineb kogudusi, kus kaksiknimesid kordagi ei registreeritud (kaardil valgega): tüdrukute puhul Hanilas, Mihkli Eestimaa osas (Liivimaal üks tüdruk), Muhus ja Saare-Jaanis, poiste puhul Hanilas, Muhus, Emmastes, Vormsil, Pühas, Tõstamaal. Harvemini kasutati kaksiknimesid Läänemaal ja saartel. Poiste kaksiknimede sageduse jagunemine sarnaneb tüdrukute nimede omaga, ent on tagasihoidlikum (vrd joonis 7).

Seega on kaksiknimede tarvituses suured erinevused, ulatudes tavapärasest praktikast peaaegu tundmata kombeni. Huvitav on, et kui Viljandimaa tõuseb silmatorkavalt esile uuendusliku joone - eestipäraste naisenimede - poolest, siis teine oluline muutus, kaksiknimede panek, on seal suhteliselt tagasihoidlik.

2 Aluskaardina on kasutatud on Eesti Keele Instituudi kohanimeandmebaasi (KNAB) kihelkonnapiiride kaardikihti. 


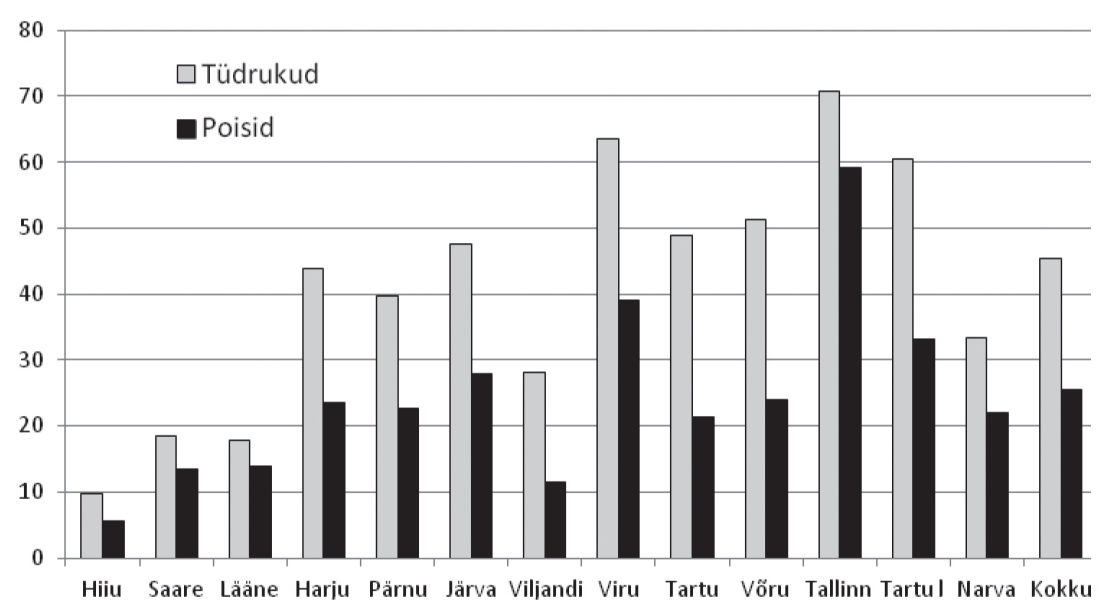

Joonis 7. Kaksiknimede kasutus 1900. aastal maakonniti

\subsection{Kogu Eesti ala}

Kui arvestada uute nimekasutusjoonte omaksvõttu (eestipärased nimed, kaksiknimed, populaarsete nimede väiksem osakaal, nimede arvu suurenemine) ja vanade tavade püsimist (laennimede kasutus) ning püüda hinnata üldist pilti, on peaaegu kõigi näitajate poolest uuenduslikumate piirkondade seas üsna ootuspäraselt Tallinn. Ainuke, millelt Tallinn idapoolsetest aladest oluliselt maha jääb, on eestipärased nimed, nende osakaalult on see linn viimaste seas. Nimedest domineerivad võõrapärased, ka laennimede kasutus on tagasihoidlik.

Tallinnale järgneb teine suurem keskus, Tartu, mis on uuendused - nii eestipärased kui ka kaksiknimed - hästi omaks võtnud. Eestipäraste nimede osakaalu poolest ületab linna Tartumaa, mis ka muudelt näitajatelt kuulub moodsama nimekasutusega alade sekka.

Tartule järgneb uuenduste vastuvõtul Võrumaa, mis torkab peale mujalgi iseloomulike joonte silma teistest mõnevõrra erineva nimevalikuga. Võrumaa uuenduslikum nimekasutus tulebki ilmselt siduda uuenduste keskpunkti, Tartumaa ja Tartu linna lähedusega.

Virumaa on kaksiknimede leviku keskmeid, eestipäraste nimede levikult ja laennimede taandumiselt jääb ta aga teistest maha. Järvamaa nimekasutust võib võrrelda ta asukohaga - jääb teiste keskele. 
Narva linn on maakondadega võrreldes üsna uuendusmeelne, näiteks kasutati seal vähe laennimesid, ent teistest linnadest jääb ta maha nii kaksiknimede kui ka eestipäraste nimede levikult.

Kõige alalhoidlikuma kasutusega on Läänemaa ja saared, nende järel Viljandimaa, Harjumaa ja Pärnumaa. Viljandimaa tõuseb esile ühe näitaja poolest - seal on Tartu linna ja maakonna järel pandud tüdrukutele eestipäraseid nimesid kõige enam.

Märkimist väärib, et ehkki praegusaegne Eesti ala jagunes toona Eestimaa ja Liivimaa kubermangu vahel, ei saa esile tuua ühtki joont, kus eesnimekasutusele iseloomulikud jooned jaguneksid põhja ja lõuna vahel.

\section{Nimekasutuse mõjutajad}

Esmalt tuleb arvesse Eesti ajalugu. Talupojad ning nende liikumisvõimalused ja meele vabastas pärisorjuse kaotamine Eestimaa kubermangus 1816. ja Liivimaa kubermangus 1819. aastal. Talupojad sõltusid seejärel maaomandi tõttu mõisnikust, kuid olid isiklikult siiski vabad. Talude päriseksostmine võttis Eesti alal väga erinevalt aega, jõukamad piirkonnad tulid sellega kiiremini toime, vähem jõukates renditi talusid veel pikka aega. Igal juhul tähendas vabadus senisest suuremat liikuvust ning sõltumatust. Nimepanekutava muutumise mõttes tähendas see rohkem kontakte - isegi kui elukohta ei vahetatud - ning vabamat suhtumist senistesse traditsioonidesse.

Pärisorjusest vabastamisega kaasnes perekonnanimede panek, mis muutis eesti senist nimesüsteemi. Eesnimedele sellel otsest mõju ilmselt polnud. Eesnimistut võis perekonnanimede panek mõjutada selliselt, et need vanad laennimed, mida lastele enam eriti ei pandud ning mis perekonnanimede panekuga isanimest (või kohanimest) perekonnanimeks said, vajusid eesnimedena unustusehõlma.

XIX sajandi tööstuslik areng tähendas tööstuskeskuste kujunemist, millega kaasnes inimeste suurem liikuvus ja koondumine eri piirkondadest ühte suuremasse keskusesse. Kindlasti tähendas see peale linlaste arvu suurenemise ka nende kaudu mõju kodukohta jäänute silmaringile ja seisukohtadele, sest kontaktid säilisid. Raudteed hakati Eestis ehitama 1868. aastal, esimesena valmis Peterburi-suunaline tee. Raudteejaamade ümber kasvasid asulad, kuhu koondus inimesi eri paigust. Näiteks Rakvere elanikkond kasvas 1870. aastast sajandi lõpuni üle kahe korra: 1870. 
aastal elas Rakveres 2664 inimest, 1897. aastal juba 5890 (EE 8: 17). Nii tööstuskeskuste kui ka raudtee arendamisel vajati haritud spetsialiste, kes tõid kaasa võõraid nimesid, mille kohalikud järk-järgult omaks võtsid. Siinse käsitluse materjalist puudutab see teema eeskätt Virumaad ja Narvat.

Majandusliku arengu kohta on Mart Laar (2005: 212) nentinud, et ehkki Põhja-Eestit on ärkamisaja kontekstis peetud Lõuna-Eestist mahajäänumaks, tuleks silmas pidada seda, et need kaks ala arenesid eri suunas: lõuna pool toetus majandus põllumajandusele, põhja pool said põllumajanduse kõrval olulise rolli tööstus ja kaubandus, eriti raudtee avamine. Ehkki Põhja-Eesti majanduslik areng oligi mõnevõrra aeglasem, tuleks samas arvesse võtta linnade suuremat osa Lõuna-Eestiga võrreldes, linnade aktiivsem elu mõjutas ka rahvuslikku liikumist (Laar 2005: 215).

Kuna Virumaad on alati läbinud olulised ühendusteed suure keskusega, võib see olla mõjutanud seda, et Virumaa on nimekasutuselt pigemini uuendusliku poole peal (nt laennimed on juba võrdlemisi harvad). Uued nimed ning vaated nimedele on sinna võinud jõuda mööda maanteed ja hiljem raudteed. Nagu kõigis piirkondades, nii on ka väikestes uuendusi paremini vastu võetud just keskuste ümbruses (vt joonis 6, mis esitab andmeid kihelkondade kaupa). Rakvere ja selle ümbrus on kaksiknimede omaksvõtmise keskne koht. Kaksiknimesid ei ole nimepanekul teadaolevalt soovitatud, seega peab see olema eeskuju mõjul levinud komme. Eeskuju oli võimalik saada kontaktide kaudu, nii et ühendusteede mõju tuleb oluliselt arvesse.

Narva oli uurimusse haaratud kui suure eesti kogukonnaga tööstuskeskus. Nimede valik oli Narvas uuemeelne, ent osa uuemaid jooni on esindamata või suhteliselt nõrgad: nimede arv on üsna suur; laennimed on jäänud tagaplaanile, ent eestipäraseid nimesid on tagasihoidlikult ja kaksiknimede populaarsus jääb kõrvalasuvale Virumaale alla; nimed on võõrapärased, ent teiste piirkondadega võrreldes silmatorkavaid erinevusi ei ole. Kujutades ette mujalt tulnud inimeste olukorda uues keskkonnas, võib oletada soovi pigem sulanduda, mitte eristuda.

Nimeandjate sotsiaalset staatust ei ole siinses käsitluses andmete ebaühtlase esindatuse tõttu vaadeldud, kuid oma roll on nimede muutumisel kindlasti olnud ka sellel, et eestlaste positsioon ühiskonnas on olnud muutumas. Suurenenud on eesti haritlaste osa (õpetajaid on rohkem) ning ka muudes valdkondades on eestlaste osakaal kasvanud, nt kaupmeeste ja muude ametimeeste seas - eestlased pole enam ainult talupojad ja 
lihttöölised ning kihistumist on nii linnas kui ka maal. Roos (1962: 413) on esile toonud, et XIX sajandi esimesel poolel ning juba XVIII sajandilgi on võõrapärase nime saanud lastel tavaliselt vähemalt üks ristivanem muulane ning uute nimede vahendamisel on olnud oluline roll ahelal „mõis - sakslaste lähikonda kuulunud ametimehed (väiksemate mõisate valitsejad, aidamehed, möldrid, kõrtsmikud jne) - talupojad“. Sama on eelmiste sajandite kohta märkinud Rootsmäe (1969: 623) ja Tiik (1977: 284). Varasema aja, XVI sajandi seisuse ja nime seoseid on uuritud (Palli 1959), ent XIX sajandi kohta taolist uurimust pole. Siinkirjutaja tähelepanekute järgi on XIX sajandi lõpu poole sagedamini nimeuuendajateks olnud vanema või ristivanemana isikud, kellel oli ameti tõttu tõenäoliselt suurem suhtlus- või silmaring, mõisarahva osa nii määrav enam polnud. 1900. aasta materjalist leiab järgmised näited: Järva-Peetris on kooliõpetaja pannud pojale nimeks Lembit, Edmund Adolf ristiisa Kanepis on kaupmees Ado, Raphaeli isa on Urvastes sepp, Normann Bernhardi isa Kanepis tallimees, Einhardi isa Kanepis rätsep, Edvini isa Simunas valitseja Henn, Selma Regina isa Räpinas sepp, Brunhilde isa Simunas urjadnik Jüri jne.

XIX sajandi alguseks oli Lembit Andreseni sõnul Eesti ala erineva haridusliku tasemega, kuna põhja ja lõuna pool oldi kooliõpetuse juurde jõutud ise ajal; sajandi keskpaiku oli külakoolide võrk lõuna pool oluliselt tihedam (Andresen 1995: 97). 1860.-1870. aastatel hakati teostama uut suunda, koolikohustust, ning tihendati oluliselt koolivõrku, eriti Eestimaa poolel (Andresen 1995: 105-106). Peale haridustaseme paranemise tähendas see maaharitlaskonna kasvu ja kindlasti ka kohapealset mõju. Laar (2005: 213-215) toob esile, et Põhja-Eesti poolel olid hariduslikult esirinnas Järvamaa ja Virumaa, tagasihoidlikumad olid Harjumaa ja Läänemaa. Liivimaa Eesti osas oli koolihariduse tase paremal järjel. Hariduse mõju kontekstis tuleb nimetada Tartumaa arengut mõjutanud Tartu linna ja ülikooli. Tartumaale koondus seetõttu juba eelärkamisajal olulisi tegelasi (Laar 2005: 208) ning Tartumaa kujunes üheks olulisemaks rahvusliku ärkamisaja liikumise keskuseks.

Nimekasutust silmas pidades tuleb nentida, et ehkki 1900. aastaks oli koolivõrk ja seega hariduse kättesaadavus Põhja- ja Lõuna-Eestis enam-vähem ühesugune, oli praeguse Eestimaa kaks korda tihedama haridusvõrgu ajalugu siiski lühike, paari põlvkonna vanune ning selle tõttu väiksema mõjuga. Parema haridustasemega Järvamaa ja Virumaa kuuluvad nimevaliku poolest julgemate ja uuenduslikemate hulka, eriti 
muidugi Virumaa. Kindlasti aitas haridustaseme paranemine kaasa silmaringi laienemisele ja võimaldas ligipääsu uuele infole: järjest rohkem loeti ajakirjandust, kalendreid, lisanduvat ilukirjandust, mis kõik pakkusid muu kõrval uusi nimesid.

XIX sajandi II poolel oli oluline roll rahvuslikul ärkamisel. Laar on mõõtnud rahvuslikku aktiivsust, arvestades ajalehtede tellimist, osalemist seltsides ja kooriliikumises, osavõttu laulupidudest, rahvaluule kogumist ja annetusi Aleksandrikoolile (Laar 2005: 193-196). Nende põhjal kokku pandud rahvusliku aktiivsuse kaart (Laar 2005: 201) kattub vähemalt osaliselt nimekasutuse alalhoidlikkuse-uuendusmeelsuse piirkondadega. Näiteks olid Laari järgi (2005: 201) vähem aktiivsed saared ja Läänemaa mandriosa, suurem osa Harjumaast oli keskmiselt või alla keskmise aktiivne, Tartumaa ja Viljandimaa olid üle keskmise aktiivsed. Nimetarvituse poolest kattuvad need alad nimekasutuses silmatorkavalt tagasihoidlike või muutusterohkete piirkondadega (tõsi, Viljandimaa puhul valikuliselt). Samas on Laar märkinud (2005: 201), et linnad on rahvuslikus liikumises olnud aktiivsemad, kui varem arvatud. Ka nimetraditsioonide muutumiselt on linnad olnud eesliikujad, v.a eestipäraste nimede poolest. Nii nimetatud tegurite kui ka sotsiaal-majandusliku ning haridusliku arengu mõju üle peetud arutelu lõpetuseks nendib Laar (2005: 217) siiski, et nende vastastikune mõju pole selge: rahvusliku liikumise aktiivsus ei sõltunud üheselt majandusest ja haridusest - jõukamad piirkonnad ei pruukinud aktiivsed olla ja vastupidi, ,ainus rahvusliku aktiivsuse reegel oli see, et reeglit polnud“.

Laiemas plaanis tuleb silmas pidada, et eestlased ei olnud nimepanekutava uuendamisel ainukesed, omakeelsed nimed olid teemaks ka nt ungarlastel, tšehhidel, soomlastel (Paikkala 2004: 118-119).

\section{Kokkuvõte}

XIX sajandi II poole muutused eesnimekasutuses on toimunud piirkonniti erineva tempoga ning eri viisil.

Linnades pandi suhteliselt rohkem kaksiknimesid ning ka nimevalik oli uuenduslikum. Eestipärased nimed linnas eelistuste hulka ei kuulunud, v.a Tartus. Maakondadest oli osa piirkondi jäänud varasema nimekasutuse juurde (saared, Läänemaa, Harjumaa, Pärnumaa): üldiseks saanud võõrapäraste nimede kõrval kasutati endiselt laennimesid; uus komme, 
kaksiknimede panemise tava, oli võrdlemisi tagasihoidlikult levinud. Osa piirkondade nimepanekutava oli oluliselt muutunud (Tartumaa, Virumaa, Võrumaa, vähem Järvamaa, Viljandimaa): kasutati laialt uuemaid võõrapäraseid nimesid, ent nende kõrvale on naisenimede poolel ilmunud eestipärased nimed, agaralt pandi lastele kaksiknimesid.

Eesnimekasutuse moderniseerumise põhjal saab praeguse Eesti ala lääne-ida suunas kaheks jagada: saared, Läänemaa, Harjumaa ja Pärnumaa esindavad alalhoidlikumaid hoiakuid, vaheala moodustavad Järvamaa ja Viljandimaa ning uuendused on kaugemale jõudnud Virumaal, Tartumaal ja Võrumaal.

\section{Kirjandus}

Andresen, Lembit 1995. Eesti kooli ajalugu. Algusest kuni 1940. aastani. Tallinn: Avita.

EE 8 = Eesti entsüklopeedia. 8, 1995. Peatoim. Toomas Varrak, Ülo Kaevats. Tallinn: Eesti Entsüklopeediakirjastus.

Hussar, Annika 1998. Eestlaste eesnimedest aastatel 1930-1990. Magistritöö. Tartu: Tartu Ülikool. Käsikiri Tartu Ülikooli raamatukogus.

Hussar, Annika 2009. Changes in naming patterns in 19th century Estonia. Discarding the names of parents and godparents. - Names in Multilingual, Multi-Cultural and Multi-Ethnic Contact: Proceedings of the 23rd International Congress of Onomastic Sciences. August 17-22. York University, Toronto, Canada. Eds. Wolfgang Ahrens, Sheila Embleton, André Lapierre. Toronto, Canada: York University, 519-525.

Hussar, Annika 2010. Changes of Estonian first names in the $19^{\text {th }}$ century. I Nomi nel tempo e nello spazio, IV. Atti del XXII Congresso Internationale di Scienze Onomastiche. Pisa, 28 agosto - 4 settembre 2005. Eds. Maria Giovanna Arcamone et al. (Nominatio. Collana di studi onomastici 7, Serie Miscellanee.) Pisa: Edizioni ETS, 193-200.

Hussar, Annika 2012. Muutused eesnimekasutuses XIX sajandil Martna ja Palamuse näitel. - Emakeele Seltsi aastaraamat 57 (2011). Peatoim. Mati Erelt. Tallinn: Eesti Teaduste Akadeemia Kirjastus, 35-59. doi:10.3176/ esa57.03.

Kiviniemi, Eero 1982. Rakkaan lapsen monet nimet. Suomalaisten etunimet ja nimenvalinta. Espoo.

Kiviniemi, Eero 2006. Suomalaisten etunimet. (= Suomalaisen Kirjallisuuden Seuran toimituksia 1103.) Helsinki: Suomalaisen Kirjallisuuden Seura.

Laar, Mart 2005. Äratajad. Rahvuslik ärkamisaeg Eestis 19. sajandil ja selle kandjad. Tartu: Kirjastus Eesti Ajalooarhiiv. 
Ministeriell $=$ Ministeriell bestätigte Vorschriften des Evangelisch-lutherischen General-Konsistoriums betreffend die Führung der Kirchenbücher (метрические книги) in russischer Sprache. 1899. С.-Петербург.

Must, Hildegard 1964. Trends in Estonian name-giving from 1900 to 1945. Names. Journal of the American Name Society 12 (1964), 42-51.

Paikkala, Sirkka 2004. Se tavallinen Virtanen. Suomalaisen sukunimikäytännön modernisoituminen 1850-luvulta vuoteen 1921. Helsinki: Suomalaisen Kirjallisuuden Seura.

Palli, Heldur 1959. Eesti isikunimedest Harju- ja Järvamaal XVI sajandil. - Keel ja Kirjandus 10, 595-608.

Rajandi, Edgar 1963. Nimevähesusest XVIII sajandi esimesel poolel. - Keel ja Kirjandus 3, 177-178.

Rajandi, Edgar, Helmut Tarand 1971. Möödunud aastakümne eelisnimed. Keel ja Kirjandus 4, 207-216.

Rajandi, Edgar, Helmut Tarand 1976. Eesti nimi läbi sajandite. - Keel, mida me uurime. Tallinn: Valgus, 131-136.

Regeln $=$ Regeln zur Schreibung der Namen mit russichen Buchstaben. EAA.3114.1.50:3. http://www.ra.ee/dgs/browser.php?tid=9\&iid $=200252072902 \&$.

Roos, Eduard 1962. Eesti eesnimede ajaloost XIX ja XX sajandi vahetusel. Keel ja Kirjandus 7, 412-421.

Rootsmäe, Lemming 1969. Võnnu kihelkonna isikunimed XVIII sajandil. - Keel ja Kirjandus 10, 623-624.

Saari, Henn 1990. Ein statistisches Modell der Vornamenwahl. XVIIth International Congress of Onomastic Sciences. Helsinki, August 13-18, 1990. Estnische Akademie der Wissenschaften. Abteilung für Humanitär- und Gesellschaftswissenschaften. (= Preprint KKI-67.) Tallinn.

Tiik, Leo 1977. Isikunimede mugandid Saaremaal XVI ja XVII sajandil. - Keel ja Kirjandus 5, 284-288.

\author{
Annika Hussar \\ eesti keele ja kultuuri instituut \\ Tallinna Ülikool \\ Narva mnt 25 \\ 10120 Tallinn \\ Annika.Hussar@tlu.ee
}




\title{
Estonian given names in the year 1900
}

\author{
ANNIKA HUSSAR
}

The article examines Estonian given names in the year 1900. The material comes from all 124 Lutheran congregations on the territory of present-day Estonia. In addition to the names themselves, other aspects of working with documents from this time are discussed (Russian language, old orthography in names). The most popular female names were Marie, Alide, and Hilda, while the most popular male names were August, Johannes, and Aleksander. Although the list of names had changed in the previous few decades, there were still examples of borrowed names belonging to the previous naming tradition (e.g. Liisa and Jaan, especially in western regions). In female names, the emerging trend of Estonian-origin names can be observed (e.g. Salme, Linda, Helmi, more in the east as well as in Viljandimaa). There are examples of names which were the most popular in one district (e.g. Hilda in Tartu or Elfriede in Tallinn) but were almost unknown in more conservative areas.

Another new trend was the use of double first names, which also grew in popularity toward the end of the 19th century. As is typical of naming trends, this innovation was primarily seen in female names. It was most prominent in Tallinn (over 70\% of girls' names), Virumaa and the Tartu area; in the west, there were still congregations where all children received single names.

As in other countries, factors influencing name usage in Estonia include industrial development, railroad construction, the growth of cities, increased mobility, the rise in the level of education, and the people's increased exposure to literature; the activity of the nationalist movement also played a role. These wide-ranging changes in people's way of life led them to adopt a more liberal attitude toward name usage.

Despite Estonia's small size, there are quite substantial regional differences in the changes in name usage. The country can broadly be divided into two regions: the conservative West (Harjumaa, Läänemaa, the islands, Pärnumaa, Viljandimaa, Järvamaa) and the innovative East (Virumaa, Tartumaa, Võrumaa). More innovative name usage was also observed in cities (in this study Tallinn, Tartu, and Narva).

Keywords: onomastics, anthroponyms, given names, double names 